\title{
Widening the scope of comparative political theory
}

\author{
Paul-Erik Korvela, University of Jyväskylä
}

Review of Hassan Bashir: Europe and the Eastern Other. Comparative Perspectives on Politics, Religion and Culture before the Enlightenment. Lexington Books, Lanham 2013, 140, ISBN 978-0-7391-3803-8

Hassan Bashir's "Europe and the Eastern Other" is an attempt to expand the scope of comparative political theory. Comparative political theory (CPT) has emerged as a new subfield of political science, its proponents arguing for a re-focusing of political theory on more wider and global dilemmas instead of its traditional focus on Western-born topics and canon of Western classics. While CPT in itself is an attempt to widen the scope of political theory, Bashir's book offers an even more wider approach, questioning some of the assumptions of CPT and pointing to the possibility that it might not be content in remaining as one of political science's subfields as its aims and assumptions make it substantially different from it.

The various scholars working on CPT tend to highlight non-Western thinkers and theories of politics as variants of critiques of Western modernity and rationality after the Enlightenment but Bashir moves farther back in time to eras when the interaction between the West and the Rest was not based on unequal power constellation in which the West is superior. In his view, the CPT attempt to include non-Western ideas regarding political philosophy into the canon of political theory as an academic discipline necessarily keeps non-Western ideas underdog and treats them as silent partners in a discourse already dominated by the West. The political as it is understood in Western political theory is already a Western discourse and any non-Western attempt to discuss it is of necessity a reaction to a debate whose rules and framework are already outlined by the West. Therefore, in the modern era there might not be any "untold stories" of perfectly preserved understandings of politics that are uncontaminated by the West, only laying dormant somewhere to be discovered by comparative political theorists. Theorists like Gandhi, Syed Qutb et alia who are occasionally elevated as the tutelary heroes of non-Western understandings of politics were in fact educated in the West and do not really represent any alternative uncontaminated by the West. Therefore, the search must be concentrated on earlier periods.

Thus, Bashir studies eras and encounters between the West and its cultural Others prior to the Enlightenment and prior to the Western domination of the discourse. Armed with these assumptions, Bashir wants to expand the scope of CPT, provide more testing ground for some of the claims already made in CPT, and to an extent also question the autogenesis of the West and to highlight the fact that the West too was influenced by encounters with its Others. 
Bashir's book contains three case studies covering historical instances of interaction between the West and its Eastern Others. First he analyzes the mid-thirteenth century traveller William of Rubruck's adventures in the land of the Mongols, whose journals form the first Western eyewitness account from their culture. Secondly, Bashir scrutinizes the first Jesuit mission to the court of the Indian Emperor Akbar the Great at the end of the $16^{\text {th }}$ century. Third case study consists of the study of the Jesuit mission in late-Ming China, especially through the journals of Matteo Ricci. These instances provide Bashir's study with encounters between the West and Others in a context which was not dominated by the West and allows him to an extent to dodge the imperialist and universalistic tendencies enshrined in political theory and its way of conceiving the political.

Bashir also wants to emphasise that through the study of non-Western ideas that have been excluded in order to preserve the universalistic approach to "the political" within political theory may reveal important developments within the Western political theory itself. Any attempt to study the canon of political theory without its marginalised Others and excluded ideas is in a sense perfunctory, as the silences and exclusions are constitutive of the canon itself. But also the constitutive elements of Western identity are interesting from this viewpoint. In the three case studies, Europeans wrote about their encounters with cultures that were in some sense superior to their own. The only solace they could find was that their religion was superior to that of Others. Given that Christianity was born outside of Europe and came from the East, the attitude of the European travellers to uphold their identity as Christians in the East bears in some sense a paradoxical tone and reveals how identities are constructed in intercultural encounters. After all, Nietzsche and the Nazis called for an eradication of Christianity and its replacement with true European religion (i.e. Scandinavian and Germanic mythology) precisely because for them Christianity was an alien, Asiatic element in European culture.

Bashir argues, in my view correctly, that we shouldn't treat modernity as a unidirectional relationship where the allegedly modern West is hegemonic and non-West is only responding to its modernity. In fact, the West has been hegemonic only for a short time in world history and still in the late eighteenth century the West was in a sense peripheral e.g. in the then Asia-centred world economy. Various theorist of globalization emphasise the Western roots of the present "global village", but in previous eras the West was the underdog in many respects. One could perhaps here also add that the present unity of the global village is more due to technical and economic reasons than to moral or political incentives. The apparent unity has emerged because technology makes it possible, not because its is wished or aimed at in a political sense and thus its political theory is lagging.

Bashir tries to move beyond the mere "convenient plurality" produced by the CPT's affirmation of non-Western theories of politics and to tackle the question why would the conception of "the political" produced by Western modernity and discipline of political science be universal. In some sense, even in CPT the non246 
Western ideas about politics remain subservient to the Western conception and form a kind of untidy fringe of Western political theory. Bashir tries to avoid this and questions the universality of the Western conception itself.

Here one could of course argue that there might indeed be no "Western conception of the political" at all. Also the West has very different traditions of thought in this respect, some of them distinctively anti-modernist. What is also significant is that, as the sinologist Francois Jullien has emphasised, even the very notion of universality itself is fundamentally and even exclusively a Western concern, born from the disputes of medieval philosophy between particulars and universals or nominalism and realism. Bashir pays attention to separation of modernity from the West, but the heart of the matter might in some sense be the practice of science itself, which is distinctively Western. Not only do the analytical methods of comparative social sciences derive from key Western concerns and bear a built-in pro-Western bias, but the whole scientific approach, especially if the aim is towards generalizations and universality, bears in some sense the same skewed attitude. The fact that many disciplines from political theory to psychology to linguistics have almost exclusively Western canons of classics hints to the fact that science itself is very much a dimension of current Western hegemony. Even those pre-modern non-Western works that far excelled their European counterparts are still treated as uneven partners in dialogues vis-à-vis the European classics. Even the relatively young discipline of International Relations, which one would due to its name expect to be international, has in reality been strongly Anglo-American and the attempts to find "The Other IR" are really only very recent developments.

Bashir's book is valuable in its emphasis on the non-Western influences on the Western canon and European cultural self-understanding itself. In my opinion, this approach should be more widely used in order to question the European autogenesis of the political. And, perhaps, we should really take a look on how science itself bears a kind of Western bias. Many of the little stories that make up the canon of Western science seem to be rather artificial in closer look. In political theory, perhaps the most interesting is the story of democracy and its alleged birth in Athens. As for example John Keane has recently argued, the art of self-government by assemblies of people who regard themselves as equals was not an invention of the Athenians and the word demokratia is also older. The myth of Athenian speciality and pre-eminence as the cradle of Western civilization is perpetuated, even though facts show that democratic assemblies flourished separately from Athens. Thus, any history of democracy (or of parliaments for that matter), would need to also consider the Ancient Eastern assemblies and the various majlis (kind of grass-root parliaments) of the Middle East. Consequently, for example Max Weber's claim that the professional politician is a character that is only found in the Occident might indeed be questioned. Science itself is not free of myths and production of narratives excluding Others. 